\title{
Kim Ki-Duk'un Bin Jip (Boş Ev)Filminin Göstergebilimsel Çözümlemesi
}

\author{
Ayşegül ÇİLINGGİ* \\ Aytekin CAN* $^{* *}$ \\ "Yaşadığımız dünya, hayal mi gerçek mi, söylemek zor" ***
}

ÖZ

Kim Ki-duk, Güney Kore sinemasının önemli yönetmenlerinden biridir. Kim Ki-duk, filmlerinde genellikle erkek karakterler üzerinden kadına yönelik şiddeti ele alarak, sistemsel bir eleştiri sunmaktadır. Bu eleştiri erkeğe toplum tarafindan verilen erk alanını tanımlarken bu öğeler göstergelerle ele almaktadır. Kim Ki-duk Bin Jip (Bos Ev) filmini 2004 yllında yönetmiştir. Kim Kiduk'un filmlerin genelinde bulunan şiddet öğesi bu filmde de intikamla birleştirilmektedir. Filmde, boş evlerde kendi evi gibi yaşayan evsiz bir adamın, bu evlerden birinde yaşayan mutsuz bir kadınla tanışması ve sessiz ama etkili bir aşk hikayesi anlatılmaktadır. Filmin genelinde Kim Ki-duk’un, Kore toplumundaki kadın- erkek ilişkilerine, aile kavramına özgü eleştiriler göze çarpmaktadır. Filmin genelinde evsiz adam hiç konuşmamaktadır. Bu durum topluma bir tepki olarak anlamlandırılabilir. Film içerisinde aidiyet kavramı da ana karakter üzerinden sorgulanmaktadır.

Çalışmada göstergebilimsel çözümleme yöntemi kullanılmıştır. Göstergebilim, yapısalcı dil çalışmalarının temellendirdiği, göstergelerin anlamlandırılmasını amaçlayan sosyal bilimler alanında kullanılan bir yöntemdir. Sinema alanında yapılan çalışmalarda bu yöntemle, görüntülerde yer alan göstergelerin tanımlanması ve çözümlenmesi amaçlanmaktadır. Çalışmada bu yöntemin seçilmesinin nedeni; Kim Ki-duk'un sinemasını şekillendirirken yoğun semboller kullanması ve göstergelerle düşüncelerini anlamlandırma yolunu seçmesidir. Bu şekilde bir anlatı yapısı yönetmen/ yazar kadar seyircinin de seyirlik eyleminden anlamlandırma aşamasına geçmesine olanak sağlamaktadır. Filmin İngilizce adı 3-Iron aslında bir golf sopasının numarasıdır. Ve bu golf sopası film boyunca bir intikam nesnesi olarak kullanılmaktadır.

Anahtar Kelimeler: Göstergebilim, Kim Ki-duk, Bin Jip (모 Ev)

\section{Semiotic Analysis of Kim Ki-duk's Movie Bin jip (3-iron)}

\author{
"İt's hard to tell that the world we live in is either a reality or a dream"
}

\begin{abstract}
Kim Ki-duk is one of the notable directors of South Korean cinema. Kim Ki-duk offers a systemic critique in his films, addressing violence against women usually through male characters. While this criticism defines the area of power given to men by society, these elements are presented with indicators. Kim Ki-duk directed the movie Bin Jip (3-Iron) in 2004. The element of violence found throughout Kim Ki-duk's movies is also combined with revenge in this movie. The movie describes a quiet but effective love story in which a homeless man who lives in empty houses as if it were his own home, meets an unhappy woman in one of these houses. Throughout the movie, Kim Ki-duk's criticism of men - women relations, and unique to the concept of family in Korean society is conspicuous. Throughout the movie, the homeless man doesn't talk at all. This can be interpreted as a reaction to society. The concept of belonging is also questioned through the main character within the movie.

Semiotic analysis method will be used in the study. Semiotics is a method used in the field of Social Sciences which is based on structuralist language studies and aims to make sense of indicators. In the studies carried out in the field of cinema, it is aimed to identify and analyze the indicators in the images with this method. The reason why this method was chosen in the study is that Kim Ki-duk uses intense symbols while shaping his cinema and chooses the way to make sense of his thoughts with indicators. In this context, such a narrative structure allows the audience as much as the director / writer to move from being just a spectator to the stage of making sense. The movie's English name, 3-iron, is actually the number of a golf club. And this golf club is used as an object of revenge throughout the movie.
\end{abstract}

Keywords: Semiotics, Kim Ki-duk, Bin Jip (3-Iron)

\section{Giriş}

Güney Kore sinemasının önemli yönetmenlerinden biri olan Kim Ki-duk, filmlerinde özellikle şiddet ve cinsellik temalarını kullanarak toplumsal bir eleştiri ortaya koyar. Filmlerinde kadın-erkek ilişkilerine

\footnotetext{
* Dr., Erciyes Üniversitesi, acilingir@erciyes.edu.tr

** Prof. Dr., Selçuk Üniversitesi, aytekcan@selcuk.edu.tr

*** Bin Jip (Boş Ev)filminin son sahnesinde yer alan bu ifade ile 11 Aralık 2020 tarihinde hayatını kaybeden filmin yönetmeni Kim Ki- duk'u saygiyla aniyoruz.

**** We respectfully commemorate Kim Ki-duk; director of the Bin Jip (3- Iron), who died on December 11th, 2020, with this statement in the last scene of the film.

Makalenin Gönderim Tarihi: 07.04.2021; Makalenin Kabul Tarihi: 21.06.2021
} 
farklı bir bakış açısıyla yaklaşan yönetmen, sinemada ses öğesinden ziyade görselliğe önem verir. Hayatı farklı şekillerde anlamlandıran filmlerinde genellikle Kim Ki-duk, kendi çocukluğundan etkilenir. Kim Kiduk, 2002 yllında Bad Guy'ın Berlin Film Festivali’nde Altın Ayı ödülünü kazanmasının ardından bir Alman gazetesine verdiği röportajda, çocukluk yıllarında ailesinden, yetişkinliğinde ise askerde şiddet gördügünü ve filmlerinde bu yüzden şiddeti işlediğini belirtir (Hummel, Akt., Zengin, 2011, s. 69). Yönetmen, Bin Jip Bos Ev) filminde modernleşmeye başlayan ama geleneksellikten de tamamen kopamayan Güney Kore toplumunun kadın- erkek ilişkilerine odaklanır. Bu filmde Kim Ki-duk, temsiller üzerinden şiddet, intikam, sessizlik, ekonomik eşitsizlik, aidiyet gibi olguları da simgelerle sunar. Filmde diyaloglar yerine simgelerin seçilmesi, filmin göstergebilimsel çözümleme yöntemi ile analiz edilmesine olanak sağlar.

Bu çalışmada, Kim Ki-duk’un Boş Ev filmi, göstergebilimsel çözümleme yöntemi ile analiz edildi. Bu çözümlemede, filmdeki göstergeler üzerinden bir anlamlandırma yapıldı. Çalışmada, göstergebilim çözümleme yönteminin kullanılmasının nedeni, yönetmenin Boş Ev filminde diyaloglardan ziyade simgeleri kullanarak metaforik anlatım tercih etmesidir. İngilizce ismi olan 3- Iron, filmdeki intikam nesnesi olan 3 numaralı golf sopasından gelir. Çalışmada Boş Ev filminden simgelerin ağırlıkta olduğu ve anlamlandırılma imkânı veren 25 görüntü seçildi. Seçilen bu görüntüler, gösterge, gösteren ve gösterilen kavramları ile görüntüde yer alan nesne ve insan olguları bağlaminda tablolar halinde incelendi. Bazı tablolarda görüntüler ikili şekilde yerleştirildi. Bunun nedeni; bazı görüntülerin birbirlerini tamamlar özellikte olmalarıdır.

Çalışmanın amacı; sinemasında simgeleri sıkça kullanan Kim Ki- duk'un bu filmindeki gösterge, gösteren ve gösterilen ilişkisinin sunulmasıdır. Türkiye'de Kim Ki-duk sineması ile ilgili çalş̧malar bulunduğu görülür. Bu çalışmalarda yönetmenin diğer filmleri (Yay, Ac1, İlkbahar, Yaz, Sonbahar, Kış ve İlkbahar vb.) üzerinden göstergebilimsel çözümleme yönteminin kullanılarak yapılan makaleleri ve yüksek lisans tezleri kapsar (Zengin, 2011; Akyel, 2015; Karakış, 2018; Keskin, 2018; Sayıc1, 2021 ). Salih Keskin'in (2018) yılında hazırladığ1 yüksek lisans tezinde, Boș Ev filmi göstergebilimsel çözümleme yöntemi ile incelendi. Keskin'in çalışmasında, Boss Ev filmi göstergeler bağlamında ayrıntılı bir şekilde analiz edilirken bu çalışmada ise aynı filmdeki göstergeler, kadın- erkek- ilişkileri ve toplumsal eleştiri kavramlarına odaklanıldı. Bu çözümleme yapıllırken göstergebilimsel çözümlemenin temelleri olan gösterge, gösteren, gösterilen unsurları nesne, insan ve mekân ögeleri ile diğer çalışmalardan farklı olarak tablolar şeklinde ele alındi.

\section{Göstergebilim}

Göstergebilim, eski Yunancada 'semeion' sözcüğüne dayanırken, Batı dillerinde, Fransızcada 'semiologie', İngilizcede 'semiottics” terimlerinin karşıllğıdır (Akerson, 2019, s. 49). İnsanların iletişimini sağlayan doğal diller, göstergelerin (sözcükler) kendi aralarında kurduklanı ilişkilerden meydana gelir. Gösterge, kendi dışında bir şeyi temsil eden ve onun yerine geçebilecek nitelikteki çeşitli biçim, olgu, vb. olarak tanımlanabilir. Göstergebilim içinde yer alan diğer önemli unsurlar olan 'gösteren' ses ya da sesler bütünü, 'gösterilen' ise kavramını işaret eder (Rifat, 2009, s. 11). Çağdaş göstergebilimin temsilcileri Charles Sanders Peirce ve Ferdinad de Saussure ve Roland Barthes'dir. Bir dilbilimci olan Saussure'un ölümünden sonra öğrencileri tarafından dil çalışmaları ile ilgili notları Genel Dilbilim Dersleri (1919) adlı eserde topland. Saussure, dili göstergelerden oluşan bir dizge olarak nitelemiş göstergebilimin ise ileride bir bilim dalı olacağını öngördü. Ayrıca Saussure göstergenin özellikleri üzerinde durarak söylem, dizge, dizge içinde değer taşıma, eş zamanlılık, nedensizlik, uzlaşımsallık ve toplumsallık kavramlara açıklık getirir (Akerson, 2019, s. 60). Göstergebilimin önemini Saussure (1985, s. 19), "Dilbilim, bu genel nitelikli bilimin bir bölïmünü teşkil edecek, göstergebilimin bulacă̆r yasalar dilbilime de uygulanabilecektir" şeklinde ifade eder. Saussure'un çağdaşı olan Peirce ise göstergebilimi mantık bilimini referans alarak yaklaşımında göstergeleri sınıflandırır. Bu sınıflandırmanın en önemli özelliklerinden biri üçlü öbeklere dayanmasıdır (Rifat, 2009, s. 30). Peirce, göstergebilimin anlamlandırma yönü üzerinde durarak göstergeler, insanlar ve nesneler arasındaki ilişkinin nasıl yapılandırıldığını anlamaya çalışır (Fiske, 2014, s. 127).

Çağdaş göstergebilim yaklaşımcılarından biri olan Barthes, göstergebilimin ele alacağı dizgeleri dil ile ilişkisi üzerinden gerçeklik sağlayacağı düşüncesine sahiptir. Bu yüzden de göstergebilimi dilbilimin bir parçası olarak tanımlar (Rifat, 2009, s. 61). Barthes, bu düşünceden hareketle, Göstergebilimsel Serïven eserinde yapısal dilbilim bağlamında göstergebilim ilkelerini, "I. Dil ve Söz; II. Gösterilen ve Gösteren; III. 
Diz̧im ve Di̊gge; IV. Düzanlam ve Yananlam" (Barthes, 1993, s. 25) şeklinde sınıflandırır. Barthes'n göstergebilim yaklaşımının merkezinde anlamlandırmanın iki düzeyi vardır; düz anlam ve yan anlam. Düz anlam, gösteren ve gösterilen arasındaki ilişkiyi tanımlar. Barthes, göstergenin herkes tarafindan bilinen anlamına işaret ederken yan anlam ise, gösterge kullanıcının, duyguları ve kültürel birikimi tarafindan şekillenir. Yan anlam özneldir ve en önemli etkeni, gösterendir. Barthes ayrıca mit, eğretileme ve düz değişmece kavramlarını da göstergebilim yöntemine kazandırdı. Barthes'a göre mit, bir şeyi düşünme, kavramsallaştırma ve onu anlamlandırmak için kullanılan kültürel bir yoldur. Evrensel bir mitten söz etmek olası değildir. Hatta mitler farklı kültürlerle karşıtlık gösterebilir. Mitler, kültürün değişen gereksinimlerine göre değişebilir. Eğretileme (Metaphor) ise bilinmeyen bir durumu bilinen kelimelerle anlamlandırmaktır. Ayrıca eğretileme benzerlik ve farklılı̆̆ eşanlamlı olarak kullanarak aracın ve anlamın aynı paradigmaya yerleştirilmesini sağlayabilir (Fiske, 2014, s. 181-189) .

Anlam kuramı çerçevesinde gelişen yapısalcılık sadece göstergebilim değil birçok disiplini kapsar, çünkü disiplinler arası bir yaklaşımdır. 1960’lı yıllarda ortaya çıkan bu yaklaşım, dilbilim, söz bilim ve yazınsal bilimin çözümlenmesinde önemli bir atılım yapılmasında önemli bir rol oynar. Diğer bilim dallarına uygulanabilen yapısalcı yöntemin bu özelliğini, Moran (2002, s. 186), şu şekilde ifade etmektedir: "Yapısalcullk, yü̈zeydeki bir takım fenomenlerin altunda, derinde yatan baz̨ kurallarn ya da yasalarn olusturduğu bir sistemi (yapiyr) aramaktr. Önemli olan şu: Sistemdeki birimler kendi başlarna bir anlam taşımazlar, sistem içinde birbirleriyle olan bağlantilander onlara anlam kazandıran, çünkü ancak o zaman bir sistemin parçast olarak ele almabilir".

Moran'ın da ifade ettiği gibi yapısalcllık derinde olanı aramaya ve bulmaya yönelik yapısıyla sistemdeki birimleri birleştirir. Yapısalcılık, yapıyı oluşturan birimlerin tek başlarına anlam taşımadıklarını ama bir yapı içerinde anlamlı bir bütün oluşturduğunu savunur. Yapısalcı araştırmacılar, anlam çözümlenmesinde dilbilimin temellerini kullanarak karşıtlıklar, gösteren/gösterilen kavramlarından yararlanarak bir anlamsal bütün oluştururlar.

\subsection{Göstergebilim ve Sinemada Anlamlandırma}

Göstergebilim çözümlemelerinde en önemli nokta, göstergelerin ve kodların sosyal kültürel anlamlarına odaklanmasıdır. Göstergeler, bir imge, bir kelime ya da bir nesne olabilir. Göstergelerin anlamları ise gösteren, gösterilen ve göndergesinin arasındaki ilişkiden oluşur. Kodlar ise toplumsal ve kültürel yorumlamalardan meydana gelir. Sinemada yan anlamı alt kodlar oluşturur ve yorumlayan "metafor" gibi sembolik anlamları içeren kavramlara başvurarak anlatıyı çözümler (Çağlar, 2012, s. 26).

Göstergebilim başlangıçta dilleri incelerken 20. Yüzyllda önemli bir sanat olan sinema ile ilişkilendirilir. Böylece 20. Yüzyılda bir bilim dalı olmaya başlayan göstergebilim, aynı yüzyılda ortaya çıkan sinemayı incelemeye başlar. Sinema göstergebilimini etkileyen iki göstergebilimci Saussure ve Peirce'dür. Sinema göstergebilimcileri olan Christian Metz, Saussure'den, Peter Wollen Peirce'den, Umberto Eco ise Saussure ve Peirce'ü eleştirirken onlardan da etkilendi (Büker, 2010, s. 13-14)

Sinema göstergebilimi üzerine ilk çalşsma 1964'de Christian Metz'in Communications'un 4 no.lu sayısında yayınlanan "sinema dil mi yoksa dil yetisi mi?" başlıklı makalesidir (Bağder, 1999, s. 144). Metz’in bu makalesinin başlğı̆ndaki soru, onun sinema göstergebilimini oluşturma çabalarının başlangıcı olarak görülebilir. Metz'in geliştirdiği sinema göstergebilimi, sinema diline yapısal dilbilim ile yaklaşır. Andrew, yenilerin lideri olarak, kabul edilen Metz'in sinemanın işlevlerine yerine getireceği koşullarla ilgili araştırmalar yaptığını ve amacının sinema içerisindeki anlamlandırma oluşumlarını ortaya koymaya çalışması olarak ifade eder (Andrew, 2000, s. 245). Metz, her sanat eserinin anlamlandırmanın belli bir unsuru olduğunu belirtir. Metz, sinemada görsel imge, basıl1 ve diğer grafikler, konuşma, müzik ve gürültü (ses efektleri) olmak üzere beş enformasyon kanalında bahseder. Bu enformasyon kanallarının çoğu işitseldir (Monaco, 2000, s. 204). Metz'in işitsel olarak ağırlıkta ele aldığ1 bu enformasyon kanalları sinemada görüntü ile birlikte anlamlandırmada önemli ögelerdir. Metz, görüntünün ise anlamını kültürel kodlarla bağlantılı olduğunu her görüntünün tek başına anlam taşısa da başka görüntülerle birleştiğinde ise yan anlamlar edindiğini savunur (Büker, 2010, s. 42).

Sinema göstergebilimi ile ilgili çalışmalar yapan diğer bir isim Peter Wollen'dır. James Monaco (2000, s. 399-400), Wollen'n Sinemada Göstergeler ve Anlam eserinin göstergebilim ile ilgili İngilizce yazılmış en önemli 
yapıtlardan biri olduğunu belirtir. Wollen, Peirce'ün göstergebilim anlayışı içerisinden yer alan öbekler özellikle de ikinci öbek (görüntüsel gösterge, belirti ve simge) daha sonra sinema göstergebilimi açısından önemli olduğunu savunur. Wollen, göstergebilimcilerin görüntüsel göstergeye kayıtsız kaldıklarını belirtirken onların bu konuda iki önyargiları olduğunun altını çizer. Ona göre, önyargıların birincisi simgesel ve raslantısal göstergeyi tercih etmeleri, ikincisi ise konuşma ve ses birimlerini seçmeleri olarak açıklarken kendisi ise sinemanın estetik yönünün göstergenin üç boyutu olan belirti, görüntüsel gösterge ve simgesel göstergelerin birleşmesi ile meydana gelmesidir. (2008, s. 126-127).

Oğuz Adanır' a (2012, s. 54) göre; sinema genel olarak psikolojik ya da simgesel bir anlam taşıyıcısı ve aktarıcısıdır. Ama bu aktarım sözcüklerin kısıtlı çerçevesi içinde değil filmdeki imgelerin sınırsız anlamı içinde gerçekleşir. Sinema, sözcüklerden daha geniş bir anlamlama kapasitesine sahiptir. Sinema, Bertolucci’nin de belirttiği gibi “İçinde yaşadığımız yüzyllın kolektif dili”dir (Güçhan, 1992, s. 5). Günümüzde anlamların daha kapalı olması, bu anlamların açıklanmasını zorunluluğunu doğurur. Göstergebilim bu anlama zorunluluğunu sistematik bir hale getirir.

\section{Kim Ki-duk'un Bin Jip (Boş Ev) Filminin Göstergebilimsel Çözümlemesi}

Kim Ki-duk, 1960 yilında Güney Kore'nin bir taşra köyünde doğmuştur. 1990’lı ylllarda Paris'te Güzel Sanatlar eğitimi alan yönetmen, 1996 yilında ilk filmi Ag-o'yu (Crocodile, 1996), 2004 y1lında ise Binj̈̈p (3-Iron) filmini yönetir. Türkiye'de Boş Ev adıyla bilinen Bin-jïp filminde diyalogları azaltıp sembolik anlatımı öne çıkaran Kim Ki-duk, 2013 yapımı Moebius filminde diyalog unsurunu tamamen ortadan kaldırır. Il-dae-il (One on One) filminde ise intikam ve adalet üzerinden toplumsal bir eleştiri sunar. $\mathrm{Bu}$ filmde diyalogları sıkça kullandığı görülür. İlk filmlerinde bireyleri ele alan yönetmen bu filmle birlikte toplumu işlemeye başlar. Kadın- erkek ilişkilerini ataerkil toplum bağlamında ele alan Kim Ki-duk, bu iliş̧kiler üzerinden toplum eleştirisini özellikle kadın karakterler üzerinden sessizlik edimi ile simgeleştirir. Yönetmenin birçok filminde heykel simgesi öne çıkar. 2020 yllında Letonya'da vefat eden Kim Ki-duk'un diğer önemli filmleri şunlardır; Nabbeunnamja (Bad Guy, 2001), Bom yeoreum gaeul gyeoul geurigo bom (Spring, Summer, Fall, Winter and Spring, 2003), Samaria / Samaritan Girl (2004, Fedakâr Kı\%, ), Hwal / The Bow (2005, Yay, ) Pieta (2012, Acı) (Kaya, 2011, s. 51-53).

Kim Ki-duk'un, 2004 yilında çektiği Boș Ev filminde, başrolde yer alan Tae-suk'un boş evlere girip orada bir süreliğine yaşaması ve o evlerden birinde karşılaştı̆̆ çaresiz bir kadın olan Sun-hwa ile gelişen olaylar anlatılır. Girdiği bu mekânları kendi eviymiş gibi kullanan Tae-suk, bazen küçük tamiratlar yaparak bazen de evin çamaşırlarını yıkayarak bir bağlamda kefaretini öder. Tae-suk, bir gün boş sandığı bir evde Sun-hwa ile tanışır ve aralarında sessiz bir aşk başlar. Sun-hwa ve Tae-suk birlikte kaçarak boş evlerde birlikte bir hayat yaşarlar. Sun-hwa'nın kocasının araya girmesiyle bir süre ayrılsalar da tekrar birlikte olmanin bir yolunu bulurlar.

\section{1. $\underline{B o s ̧ ~ E V ~ F i l m i n i n ~ G o ̈ s t e r g e b i l i m s e l ~ C ̧ o ̈ z u ̈ m l e m e s i ~}$}

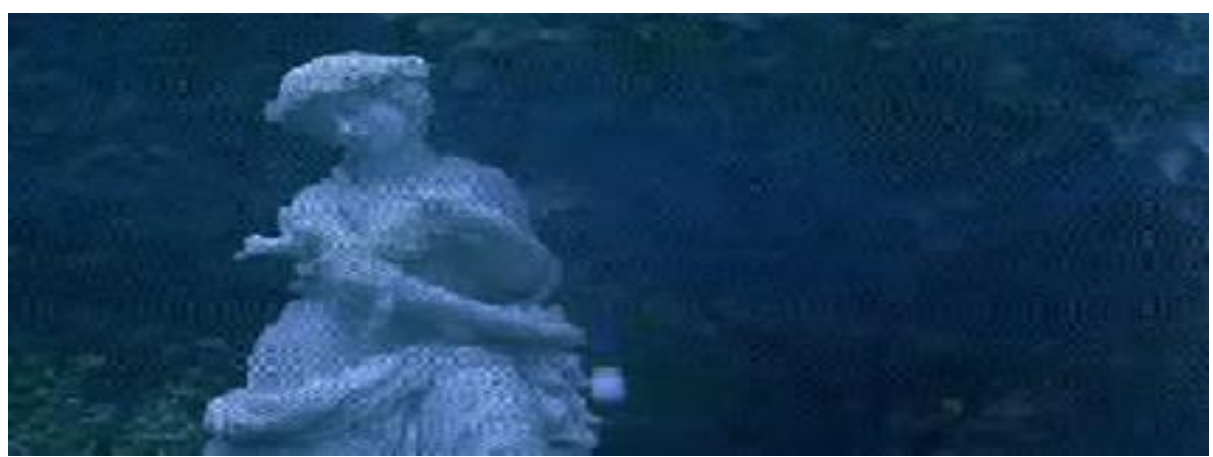

Resim 1. Kadın Heykeli 
Tablo 1

\begin{tabular}{|l|l|l|}
\hline Gösterge & Nesne & Nesne \\
\hline Gösteren & Golf topu & Kadın heykeli \\
\hline Gösterilen & Şiddet, İntikam & Masumiyet, Korumasız bir kadın \\
\hline
\end{tabular}

Filmin başında yer alan bu görüntüde kadın heykeline file arkasından atılan golf topu dikkat çeker. Golf topu ilerleyen görüntülerde önemli bir metafor olarak karşımıza çıkar. Filmde, golf topu intikam duygusunu simgeler. Bir kadının temsilinin bir heykel olarak seçilmesinin nedeni, kadın temsilinin ataerkil toplumlarda tepkisiz edilgen bir nesne olarak görülmesidir.

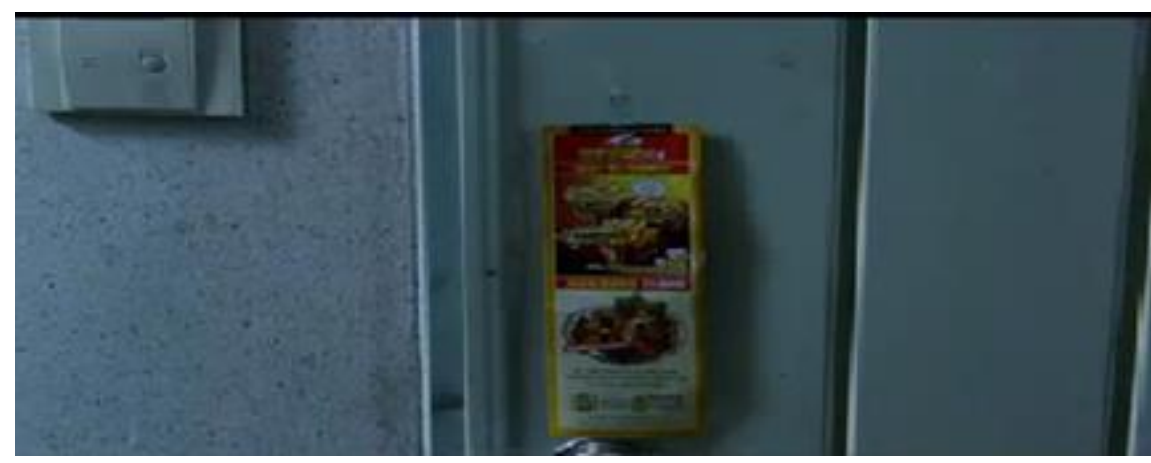

Resim 2. Boş ev

Tablo 2

\begin{tabular}{|l|l|l|}
\hline Gösterge & Nesne & Nesne \\
\hline Gösteren & Kapı kolu & Bir yemek el ilanı \\
\hline Gösterilen & Bir ev imgesi, bir yuva & Kapıdan alınmamış ilan, Boş ev \\
\hline
\end{tabular}

Resim 2'de ilk göze çarpan beyaz kapı zemininde asılı olan renkli yemek el ilanı, evin boş olduğuna işaret eder. Filmin ana kahramanı olan Tae-suk, önce bu el ilanlarını dağıtır, sonrasında ise el ilanlarının kapılardan alınmadığı evlere girerek orada bir gece geçirir.

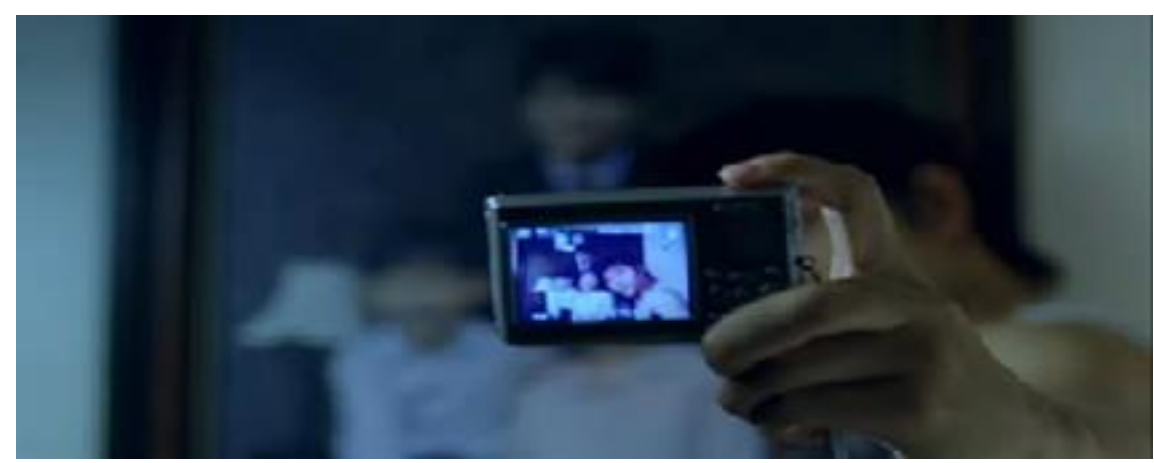

Resim 3. Aile fotoğrafi

Tablo 3

\begin{tabular}{|l|l|l|}
\hline Gösterge & İnsan & Nesne \\
\hline Gösteren & Fotoğraf çeken adam & Duvardaki aile fotoğrafi \\
\hline Gösterilen & Yalnız bir adamın, bir ailenin parçası olmaya çalışması & Mutlu bir aile tablosu \\
\hline
\end{tabular}

Resim 3'teki görselde, boş evlere giren Tae-suk, kendini evinde hissetmek için aile fotoğrafi ile kendini özdeşleştirir. Orada kendi evi gibi uyur, duş alır ve yemek pişirir. Ayrıca o evin, ailenin bir parçası olma adına aile fotoğraflarına kendisini de katarak aile duygusunu yaşamaya çalışır. Aile fotoğrafları aidiyet 
duygusunun temsilidir. Ait olma, insanların duygusal bir ihtiyacıdır ve bu ihtiyaç farklı şekillerde giderilebilir. Filmde Tae-suk, her insanın içerisinde taşıdığı bir yere ait olma duygusunu bu şekilde bastırır.

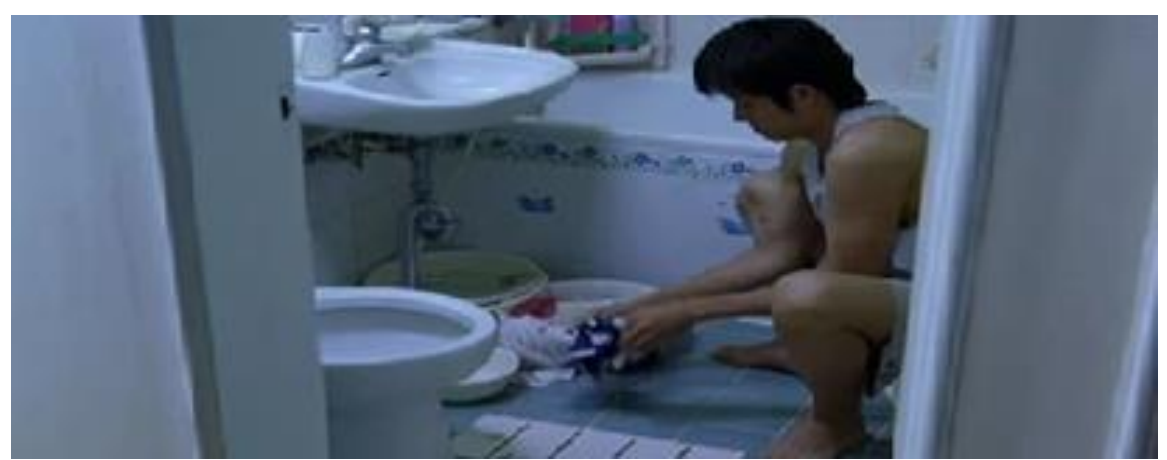

Resim 4. Kefaret

Tablo 4

\begin{tabular}{|l|l|l|}
\hline Gösterge & İnsan & Mekân \\
\hline Gösteren & Çamaşıı yikayan adam & Bir banyo \\
\hline Gösterilen & Ev halkının çamaşıllarının yıkanması & Bir evin en mahrem yerinde olma \\
\hline
\end{tabular}

Resim 4'te Tae-suk evlerin banyosunda ev halkının çamaşırlarını yıkayıp asarak yaptığı şeyin kefaretini ödemeye çalışır. Aynı şekilde diğer evlerde de temizlik vb. işler yapar. Ayrıca bir evin banyosunu kullanarak, ev halkının mahremiyetine ortak olur.

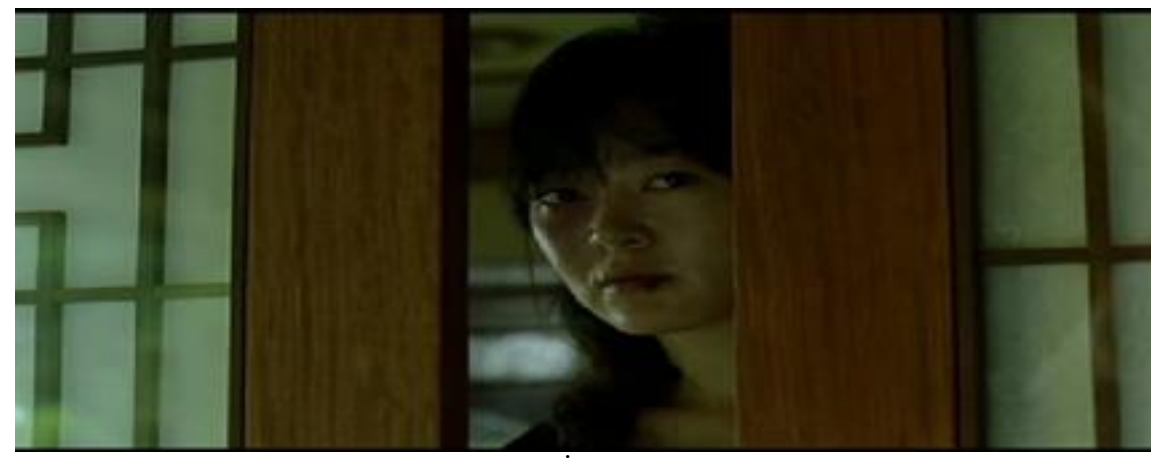

Resim 5. İzleyen kadın

Tablo 5

\begin{tabular}{|l|l|l|}
\hline Gösterge & İnsan & İnsan \\
\hline Gösteren & Yüzü morluklarla dolu bir kadın & Yabancı evlere giren adamı gözetlemek \\
\hline Gösterilen & Şiddet gören, kendi evinde sessizlikle yaşayan bir kadın & Bir başkasını başka bir evdeymiş gibi gözetlemek \\
\hline
\end{tabular}

Resim 5'te yer alan Sun-hwa, Tae-suk'u izler. Tae-suk evin içinde başka birinin yaşadığını fark etmeden diğer evlerdeki alışkanlıklarını sürdürür. Sun- hwa ise kocası yüzünden o evin içinde adeta bir gölge gibi yaşar. Yüzünden birinden fiziksel şiddet gördüğü anlaşılan Sun- hwa belki de gölge olmaya zorlandığı hissi uyandırır. Sun- hwa'nın Tae-suk'u gözetlemesi, insanların zaaflarından biri olan izleme davranışını ifade eder. Sun- hwa'nın izleme edimi, haz alma duygusundan farklı olarak bu yabancı adamın evinde ne yaptığını anlamaya yönelik bir davranıştır. 


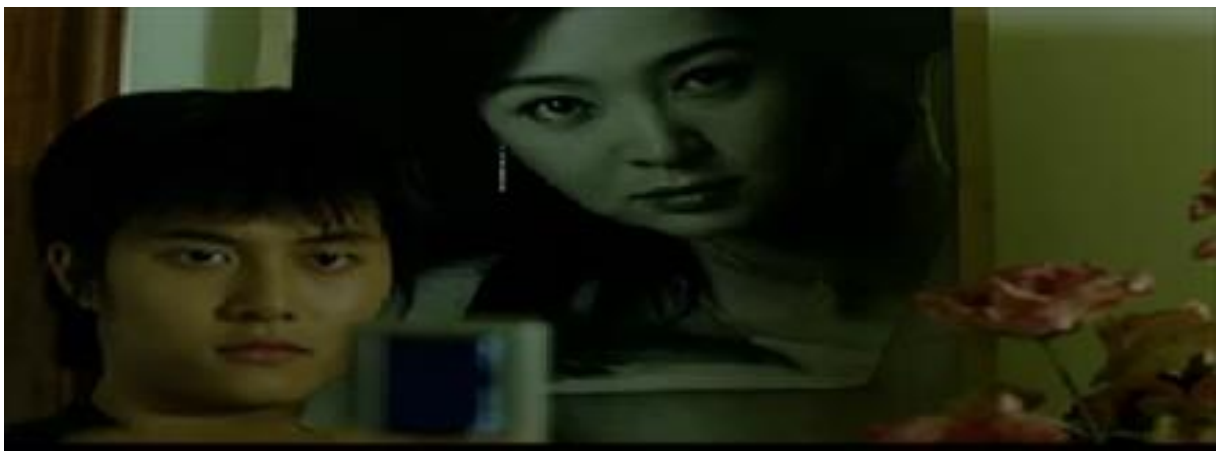

Resim 6. Tae-suk ve Sun- hwa

Tablo 6

\begin{tabular}{|l|l|l|}
\hline Gösterge & İnsan & Nesne \\
\hline Gösteren & Fotoğraf çeken adam & Kadın fotoğrafi \\
\hline Gösterilen & Güzel bir kadınla çekilen, bir sevgili fotoğrafı & Soğuk bakı̧̧lı, güzel bir kadın fotoğrafı \\
\hline
\end{tabular}

Resim 6'da eve giren Tae-suk, diğer evlerde aile fotoğrafları ile kendini özdeşleştirirken bu sahnede Sun- hwa fotoğrafı ile aynı kadraja girmeyi tercih eder. Bu tercih, Tae-suk'un bir sevgiliye, güzel bir kadına olan ihtiyacını yani yaşadığı duygusal boşluğu anlatır. Sun-hwa'nın yüzündeki soğuk ifade ise mutsuzluğunu gösterir. Tae-suk, bu fotoğrafla bir kadınla birlikte olduğu hissini yaşar. Böylece Tae-suk'un aile fotoğraflarına olan ilgisi, aşk duygusuna doğru yön değiştirmiş olur.

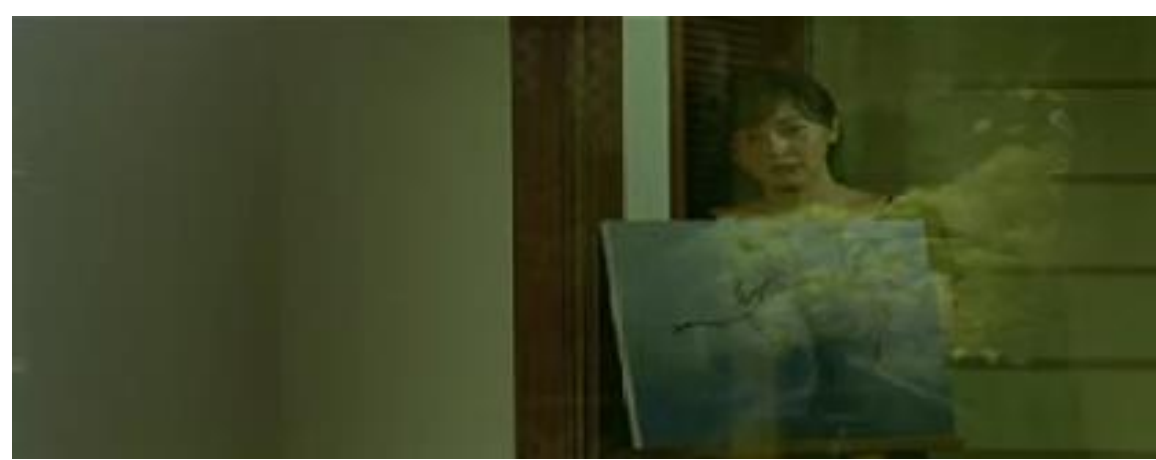

Resim 7. Bahar

Tablo 7

\begin{tabular}{|l|l|l|}
\hline Gösterge & İnsan & Nesne \\
\hline Gösteren & Penceren izleyen kadın yansıması & Baharı temsil eden bir tablo \\
\hline Gösterilen & Seyretme ve merak duygusu & Sarı, canlılı̆̆1 ve mavi özgürlüğü temsil eder \\
\hline
\end{tabular}

Resim 7'de canlllı̆̆1 temsil eden sarı renkteki çiçekli ve özgürlüğün rengi olan mavi zeminli tablonun arkasına saklanan kadın (Sun- hwa) imgesi, mutluluk ve özgürlügün geride kaldığını temsil eder. Camdaki Sun-hwa, adamın ne yaptığını merak duygusu ile izler. Bu görüntüde Sun-hwa, izleme edimini gizlenmeden yaparak kendini fark ettirme çabasındadır. 


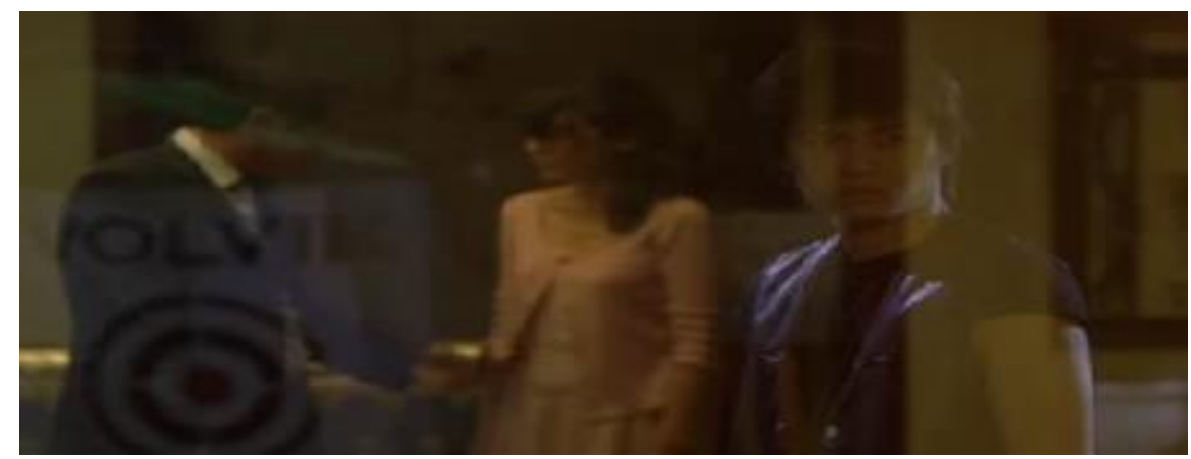

Resim 8. Merak

\section{Tablo 8}

\begin{tabular}{|l|l|l|}
\hline Gösterge & İnsan & İnsan \\
\hline Gösteren & Kavga eden karı koca & Yansımadaki adam \\
\hline Gösterilen & $\begin{array}{l}\text { Aile içinde yaşanan bir tartışma, kocanın sözlerine } \\
\text { rağmen kadının sessizliği }\end{array}$ & $\begin{array}{l}\text { İzleyici konumunda olan adam, yansımada kadının } \\
\text { yanında görünüyor. }\end{array}$ \\
\hline
\end{tabular}

Resim 8'de evdeki koca imgesi, sürekli bağıran, Sun-hwa'nın yüzündeki morlukların sebebi olarak görülürken, Sun-hwa sessiz kalarak bir boyun eğme davranışı gösterir. Onları izleyen Tae-suk'un yansıması bu esnada Sun- hwa'nın yanı başında durur. Yanında olmak edimi, birliktelik çağrıştıran bir olgu olarak aynı tarafta olmak anlamına gelir. Bu kez camın diğer yanında yer alan adam (Tae-suk) imgesi, kendini gizlemeden, sanki onlarla bir bağlantısı varmış gibi izlemeye devam eder.

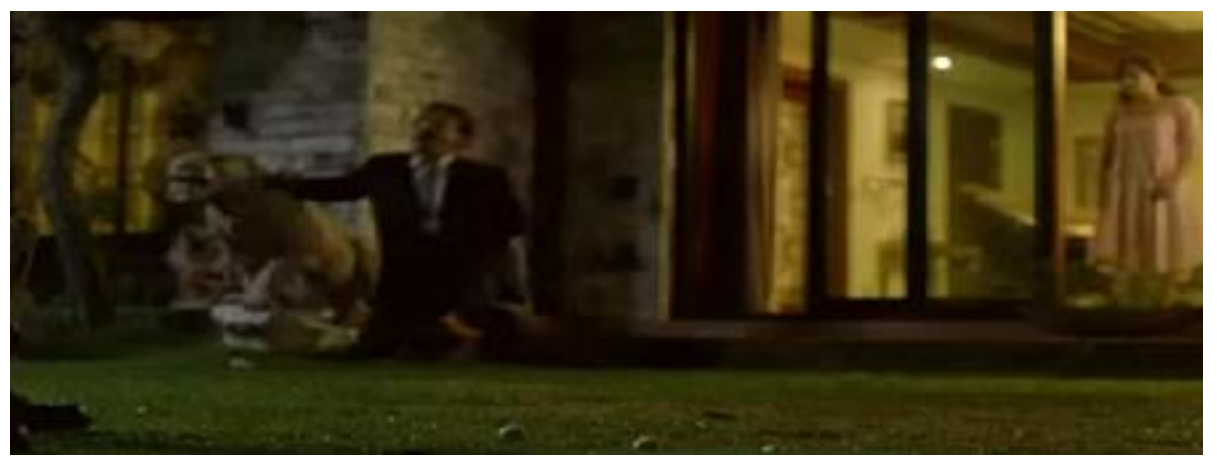

Resim 9. Aslan Heykeli

Tablo 9

\begin{tabular}{|l|l|l|}
\hline Gösterge & Nesne/İnsan & İnsan \\
\hline Gösteren & Golf topu/aslan heykeli / adam & Kadın \\
\hline Gösterilen & Güç göstergesi olan aslan, intikam nesnesi olan golf topu ve adam & İzleyen, şiddete tepkisiz kadın \\
\hline
\end{tabular}

Güç sembolü olan aslan heykelinin yanında duran Sun-hwa'nın kocası güçlü bir simge olarak karşımıza çıar. Sonrasında ise, golf oynayan Tae-suk ve Sun-hwa'nın kocasina golf topuyla saldırarak ona yaptıklarını ödetmiş olur. Sun-hwa'nın kocası güç sembolü olan aslan heykelinin yanına yığılırken, olanları izleyen Sun-hwa, hiçbir şey yapmayarak, sessizce intikam alır. Filmin başında gösterilen golf topu burada bir intikam nesnesine dönüşür. 


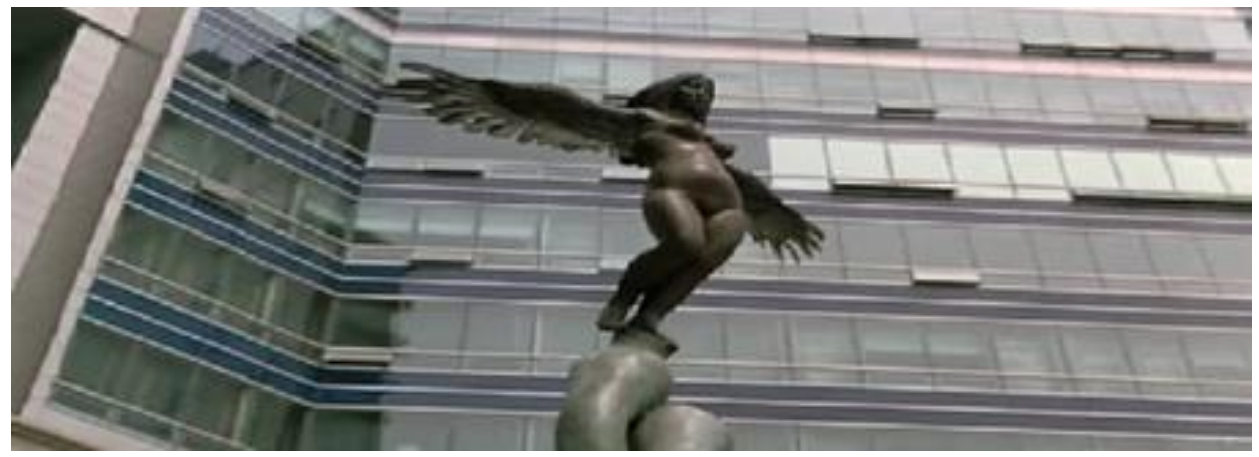

Resim 10. Kanatlı kadın heykeli

Tablo 10

\begin{tabular}{|l|l|l|}
\hline Gösterge & Nesne & Nesne \\
\hline Gösteren & Modern bir bina & Kanatlı kadın heykeli \\
\hline Gösterilen & Modernizm, yüksek bir bina & Özgürlük imgesi \\
\hline
\end{tabular}

Resim 10'da evden beraber kaçan Tae-suk ve Sun-hwa ilan dağıtmaya başlarlar. İlan dağıtmak için modern bir bina seçerler. Bu binanın önünde kanatlı bir kadın heykeli vardır. Bu heykel, evden kaçan Sunhwa ile özdeşleştirilerek, kadının özgürlüğünü kazanması olarak ifade edilir. Böylece evden, kocasından kaçan Sun-hwa, Tae-suk sayesinde bir özgürlük kazanmış olur.

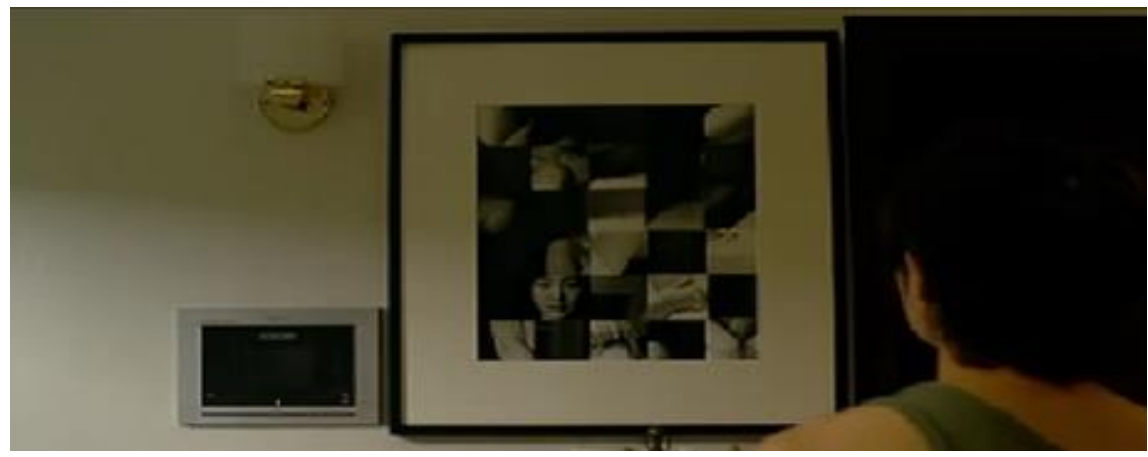

Resim 11. Parçalar

Tablo 11

\begin{tabular}{|l|l|l|}
\hline Gösterge & Nesne & İnsan \\
\hline Gösteren & $\begin{array}{l}\text { Bir kadının vücudundan farklı parçalardan oluşan } \\
\text { bir fotoğraf }\end{array}$ & Fotoğrafa bakan adam \\
\hline Gösterilen & $\begin{array}{l}\text { Bir kadının parçalanmışlı̆̆ı, vücudunun farklı } \\
\text { yerlerini fotoğrafta farklı yerlere koyarak anlatmak }\end{array}$ & $\begin{array}{l}\text { Parçalanmış bu fotoğrafa bakan } \\
\text { adam, kadının yüzüne odaklanmıs. }\end{array}$ \\
\hline
\end{tabular}

Filmin ana karakterleri olan Tae-suk ve Sun-hwa gizlice apartman dairesine girerler. Bu dairede birçok fotoğraf bulunması, bu mekânın bir fotoğrafçıya ait olduğu izlenimi verir. Bu fotoğrafların birçoğu pornografik görüntülerden oluşur. Resim 11, bir kadının vücudunun farklı bölgelerinin tek tek fotoğraflanarak çerçeve içine yerleştirildiği bir kolajdır. Bu kolaj, bir kadının hayatının parçalanmışlığını, bütünleşmemiş hayatı simgeler. Tae-suk'un bu kolaja dikkatlice bakması bir aşinalık kazanmaya çalışmasını anlatır. Kolajdaki kadın vücudunun parçalı sunumu, fetiş boyutunda kadının arzu nesnesine dönüștürülmesi ile tanımlanabilir. 


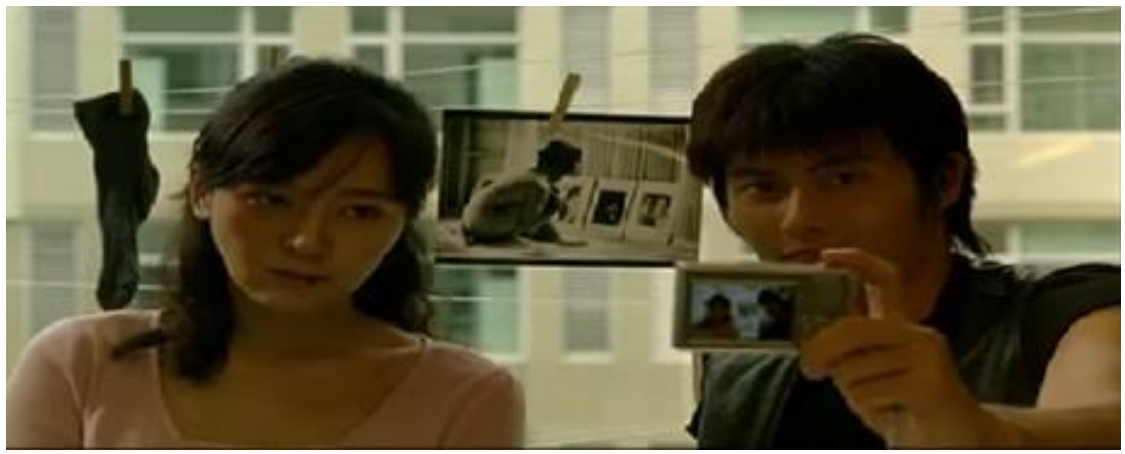

Resim 12. Fotoğraf

Tablo 12

\begin{tabular}{|l|l|l|}
\hline Gösterge & Nesne & İnsan \\
\hline Gösteren & Başka fotoğrafları izleyen kadın imgesi & Beraber fotoğraf çekilen adam ve kadın \\
\hline Gösterilen & Filmin genelinde bulunan izleme olgusu & Birlikte boş evlere ait olma isteği \\
\hline
\end{tabular}

Resim 12'de filmin genelinde olan izleme öğesi, askıda yer alan diğer fotoğraflara bakan kadın fotoğrafi üzerinden tekrar kullanılır. Bu fotoğrafta izleme ve izlenme edimleri bir arada kullanılmaktadır. Tae-suk ve Sun-hwa fotoğraf çekilerek bu izlemeye ortak olurlar. İzleme edimi film içerisinde karakterlerin üzerinden sürekli olarak karşımıza çıkar. Askıdaki fotoğraftaki kadın da izleme edimine katılarak, seyirci de izleyen konumuna getirilir.

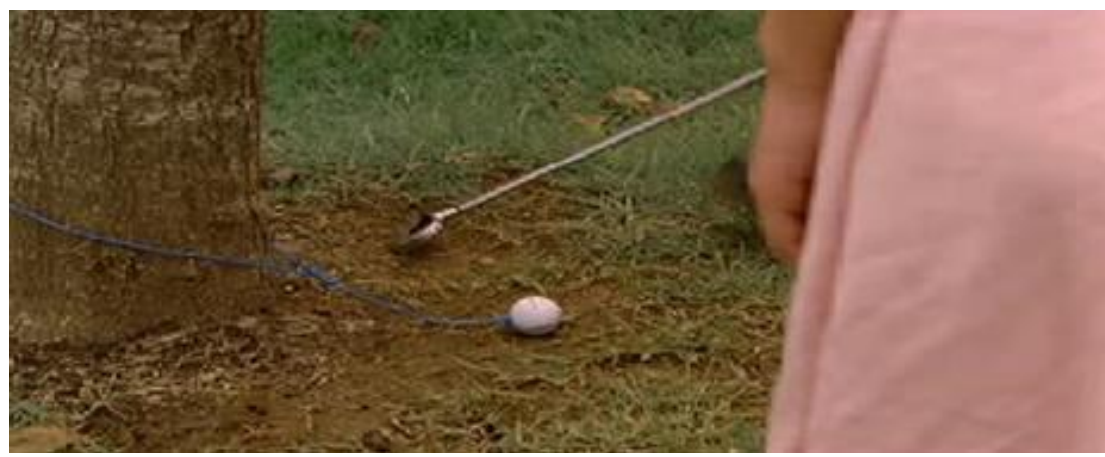

Resim 13. Ağaca bağlı golf topu

Tablo 13

\begin{tabular}{|l|l|l|}
\hline Gösterge & Nesne & İnsan \\
\hline Gösteren & Ağaca bağlanan Golf topu & Golf topuna vurmaya çalışan adam ve ona engel olan kadın \\
\hline Gösterilen & Sürekli betimlenen intikam duygusu & $\begin{array}{l}\text { İntikam duygusu ile ağaca bağlanan golf topuna vurmaya } \\
\text { hazırlanan adam ve önünde dikilen kadın figürleri }\end{array}$ \\
\hline
\end{tabular}

Resim 13’te, Golf topu göstergesi film boyunca bir intikam nesnesi olarak betimlenir. İntikam alma duygusundan vazgeçemeyen adam sürekli olarak ağaca bağladığı topa vururken görülür. Tae-suk, topa vurmak isterken Sun-hwa ona engel olamaya çalışır. Sun- hwa'nın bu davranışı, Tae-suk'un intikam duygusunu engellemeye yönelik olsa da Tae-suk topa vurmaya devam eder. 


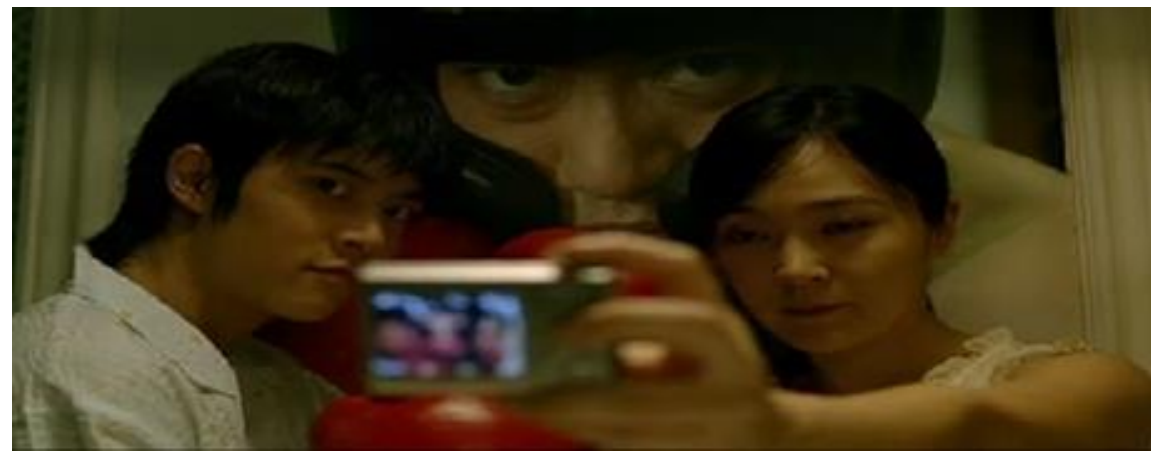

Resim 14. Boksör

Tablo 14

\begin{tabular}{|l|l|l|}
\hline Gösterge & Nesne & İnsan \\
\hline Gösteren & Boksör fotoğrafi & Beraber fotoğraf çekilen adam ve kadın \\
\hline Gösterilen & Güç simgesi olan boksör fotoğrafi & Kadın ve erkeğin birlikte daha güçlü olduklarını göstermeleri \\
\hline
\end{tabular}

Resim 14'te, Tae-suk ve Sun-hwa'nın girdikleri boş evde bulunan, sahibine ait olan boksör fotoğrafı güç olgusunu simgelerken, beraber fotoğraf çekilerek bu güce ortak olurlar. Tae-suk ve Sun- hwa artık bir bütün olarak hareket ederek boş evlerde birlikte yaşarlar. Bu fotoğraf, bir hayatı bir kaderi birlikte paylaşmanin gücünü simgeler.

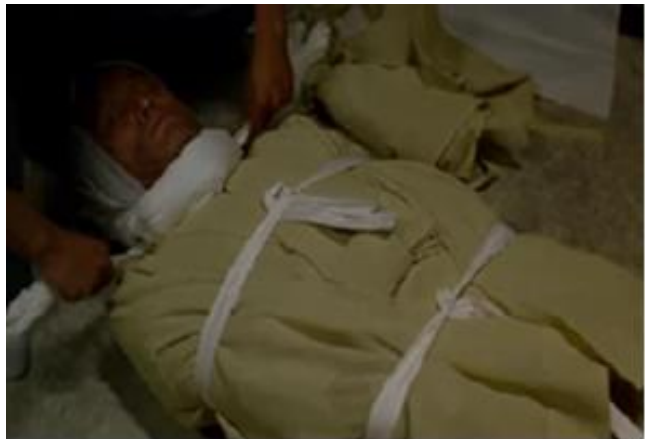

Resim 15. Ceset

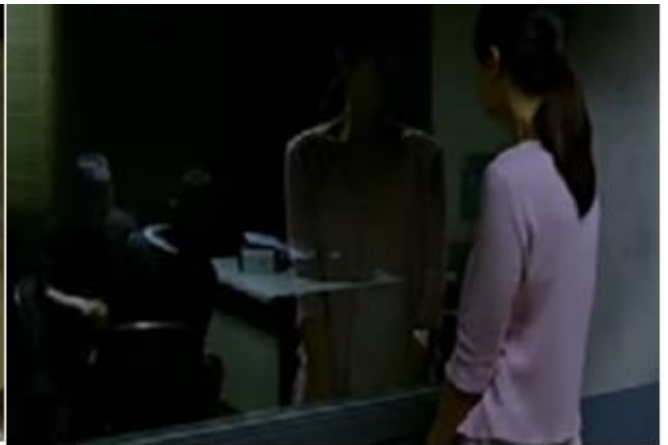

Resim 16. Sorgu odas1

Tablo 15-16

\begin{tabular}{|l|l|l|}
\hline Gösterge & İnsan & İnsan \\
\hline Gösteren & Ölü, kefenlenmiş bir ceset & Sorguyu izleyen kadın imgesi \\
\hline Gösterilen & $\begin{array}{l}\text { Geleneksel bir kefenleme, aileden } \\
\text { biri gibi cenazeyi hazırlamak }\end{array}$ & $\begin{array}{l}\text { İki erkek arasındaki güç mücadelesini izleyen kadın } \\
\text { imgesi, filmin geneline hâkim olan yansıma olgusu }\end{array}$ \\
\hline
\end{tabular}

Resim 15'de Tae-suk ve Sun-hwa için girdikleri evde buldukları ölü adamın cesedini temizlemek, onlar için sıradan (diğer evlerde çamaşır yıkamak gibi) bir iştir. Cesedi geleneksel bir şekilde kefenlemek, sanki aile içerisinde ölen bir kişiye yapılan cenaze merasimini gerçekleştirmek, filmin genelinde olan aile aidiyeti duygusunu ön plana çıkarır. Resim 16'da ise, karakolda polis şiddet edimine karşı Tae-suk'un sessizliğine devam ettiği görülür. Onları izleyen Sun-hwa imgesi, film boyunca var olan yansımadan izleme görüntüsünü andırır. Sun-hwa film içerisinde yer yer gölge konumunda kalmıştır, bu sahnede de bu konum tekrarlanir. 


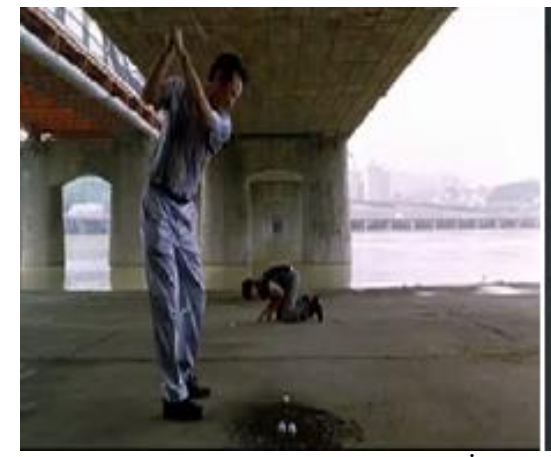

Resim 17. Sun- hwa'nın kocasının İntikamı

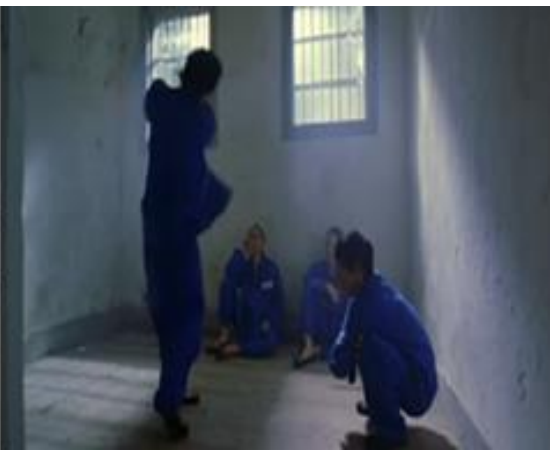

Resim 18. Taklit

Tablo 17-18

\begin{tabular}{|l|l|l|}
\hline Gösterge & Nesne & Insan \\
\hline Gösteren & Golf topu & Gerçek ve hayali olarak golf oynayan insanlar \\
\hline Gösterilen & $\begin{array}{l}\text { Golf topu, film boyunca bir intikam } \\
\text { nesnesi olarak sunulur. }\end{array}$ & $\begin{array}{l}\text { Resim 17'de intikam alan koca figürü iken resim } \\
\text { 18'de, intikam alan mahkûm edilen adamdır. }\end{array}$ \\
\hline
\end{tabular}

Resim 17'deki Sun-hwa'nın kocası, intikam almak için golf topunu kullanır. Filmin önceki sahnelerinde Tae-suk'un Sun- hwa'nın kocasından intikam almak için aynı nesneyi kullanması, gücün el değiştirmesini işaret eder. Bu sahnede, aynı kadın için, aynı şekilde ve aynı nesneyle alınan intikam üzerinde durulur. Resim 18'de ise mahkûm olan Tae-suk, hapishanede hayali olarak bile olsa filmin intikam nesnesi olarak sunulan golf topuna vurmaya çalışması, intikam alacağının işaretlerini verir.

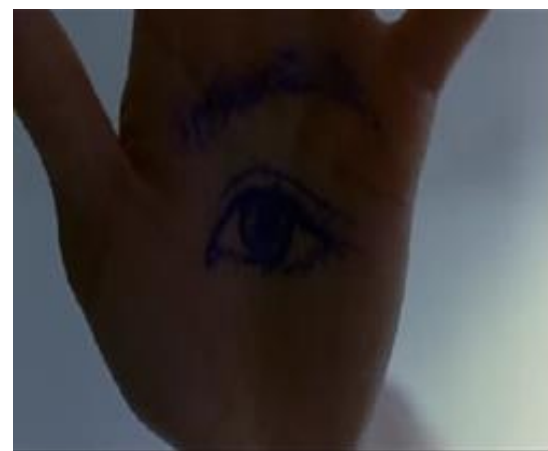

Resim 19. Göz

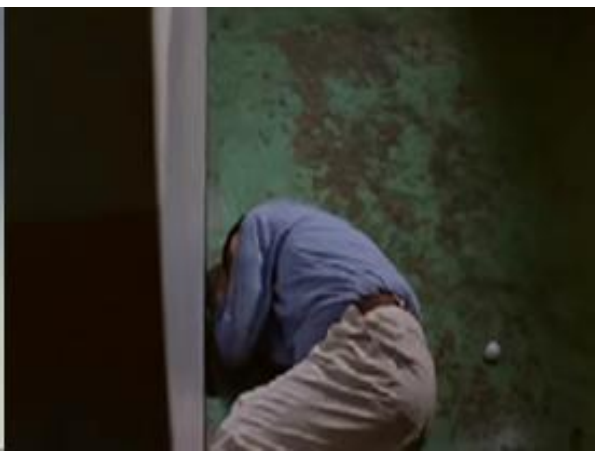

Resim 20. Tae-suk'un İntikam1

Tablo 19-20

\begin{tabular}{|l|l|l|}
\hline Gösterge & Nesne & İnsan \\
\hline Gösteren & El içerisine yazılan göz imgesi & Golf topu ile yaralanmış, yerde yatan insan \\
\hline Gösterilen & $\begin{array}{l}\text { Göz imgesi ile her şeyin görüldüğ̈̈, görmenin } \\
\text { hissetmeyle birlikte kullanılabileceği }\end{array}$ & $\begin{array}{l}\text { Polisin yaptıklarına karşı, yine intikam nesnesi } \\
\text { olan golf topuyla onu yaralama }\end{array}$ \\
\hline
\end{tabular}

Resim19'da bulunan el içinde göz imgesi, her şeyin sadece gözle görülemeyeceğini anlatırken filme hâkim olan izlemek edimine vurgu yapılır. Filmin bu sahneden önceki sahnelerinde Tae-suk, hücrede gardiyanın arkasından giderek, kendini gizleme davranışı göstermesi gizlenmenin yani gölge olmaya işaret eder. Resim 20'de ise, film boyunca intikam nesnesi olarak karşımıza çıkan golf topuyla alınmış bir intikam vardır. Tae-suk, kendisini aşağılayan, döven ve dövdüren polisi golf topu ile yaralayarak intikam alır. 


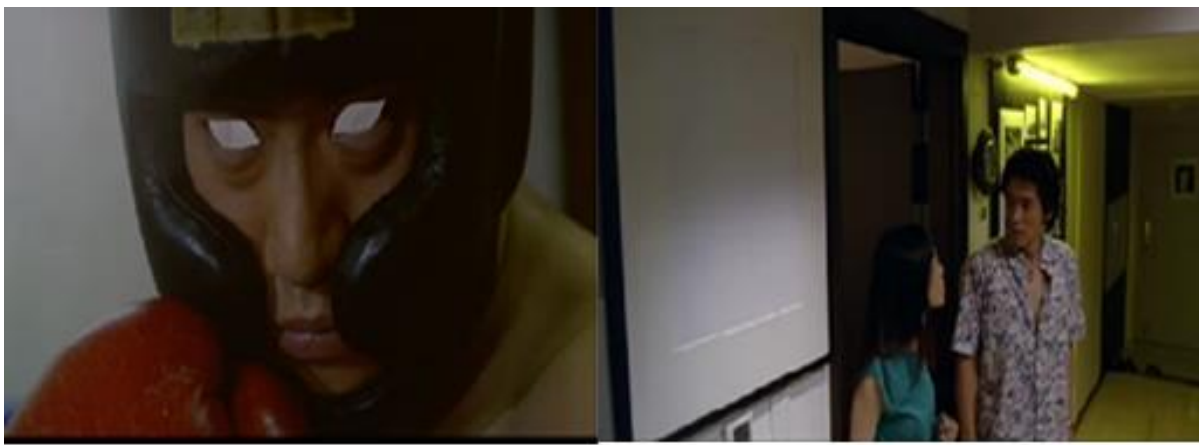

Resim 21. Gözleri oyulmuş boksör

Resim 22. Boş çerçeve

Tablo 21-22

\begin{tabular}{|l|l|l|}
\hline Gösterge & Nesne & İnsan \\
\hline Gösteren & Gözleri oyulmuş boksör resmi/ çevresinden alınmış fotoğraf & Boş çerçeve önünde duran korkmuş insanlar \\
\hline Gösterilen & $\begin{array}{l}\text { Girilen evlerde görülen muamelelere cevap olarak, dayak } \\
\text { yenilen evde gözleri oyulan boksör resmi, fotoğrafçının } \\
\text { evinde ise kadın parçalarından oluşan fotoğrafın alınması }\end{array}$ & $\begin{array}{l}\text { Evde yalnız olduklarını düşünen çiftin boş } \\
\text { çeçeveyi görünce yalnız olmadıklarını anlayıp } \\
\text { korkmaları }\end{array}$ \\
\hline
\end{tabular}

Gözleri oyulmuş boksör resmi, kalınan evlerden birinde yenilen dayağa karşı tepkiyi başka bir nesneye yöneltmeye işaret ederken bu tür edimler Freud'un savunma mekanizmaları içinde yer alan 'yön değiştirmeye' örnek olarak verilebilir. Fotoğrafçının evinden alınan fotoğraf ise, bir kadının vücudunun farklı parçalarından oluşan bir fotoğraftır. Bu fotoğraf çevresinin boş bırakılması ve diğer resimdeki gözleri oyulmuş boksör fotoğrafı bir intikam ve kaybetme duygusunu yansıtmaktadır.

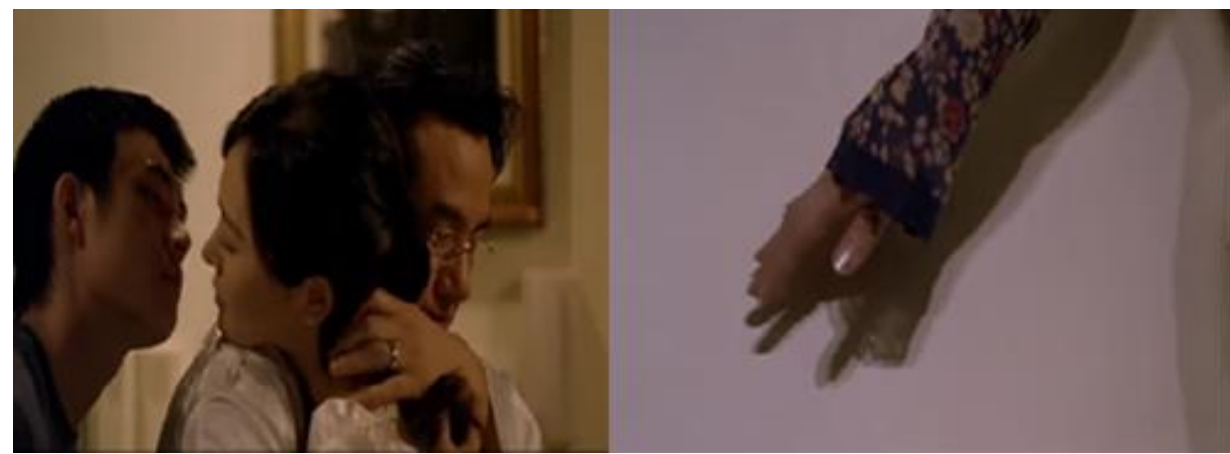

Resim 23. Yakınlaşma

Resim 24. Gölge

Tablo 23-24

\begin{tabular}{|l|l|l|}
\hline Gösterge & İnsan & Nesne \\
\hline Gösteren & $\begin{array}{l}\text { Biri gölge gibi yaşayan ve diğeri gerçekte } \\
\text { kadınla birlikte olan iki farklı adam }\end{array}$ & Bir elin duvara vuran gölgesi \\
\hline Gösterilen & $\begin{array}{l}\text { Gerçeklik ve hayal arasında sıkışan bir } \\
\text { kadın ve üçlü bir aşk üçgeni }\end{array}$ & $\begin{array}{l}\text { Kolların açılması özgürlüğ̈ü temsil ederken, gölge } \\
\text { ise yansıma olgusuna bir gönderme yaparak } \\
\text { hapishaneden çıkan adamın özgürlügünü simgeler }\end{array}$ \\
\hline
\end{tabular}

Resim 23'te biri gölge gibi yaşayan diğeri ise tüm gerçekliğini ortaya koyan iki adam arasında sıkışıp kalan Sun-hwa görülür. Sun-hwa kocasına sar1lırken aslında arkasından diğer adama sevgisini gösterir. Film başından beri yaşanan ikilem, bu sahnede bir çözüme ulaşmıs, Sun-hwa kocasını değil gölgelerde, yansımalardaki Tae-suk'u tercih eder. Resim 24'te ise özgürlügün yansımasını yakalamaya çalışan kadın, adamın gölgesinde birleşmektedir. Hapishaneden çıkan Tae-suk filmin başından beri olduğu gibi gölgelerde yaşamayı seçer. Bu görüntü ile Sun-hwa'nın da Tae-suk'un gölgelerde sürdürdüğü hayatını tercih ettiğini gösterir. 


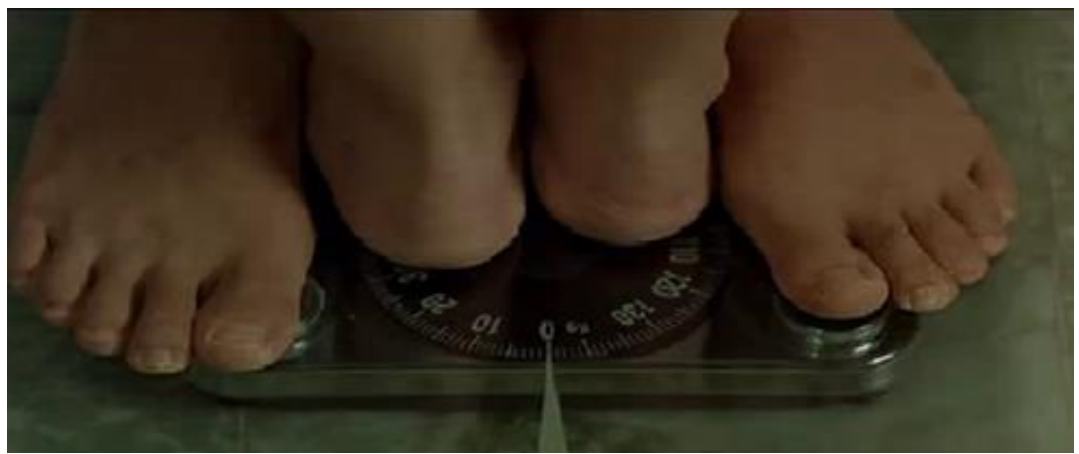

Resim 25.Teklik

Tablo 25

\begin{tabular}{|l|l|l|}
\hline Gösterge & Insan & Nesne \\
\hline Gösteren & Bir erkek ve bir kadının tartı üzerindeki iki ayă̆ı & -0- ağırlı̆̆ını gösteren tartı \\
\hline Gösterilen & Bir kadın ve erkeğin tekliğe ulaşması. & $\begin{array}{l}\text { Tartıda iki insanın ağırlığının olmaması yokluğu işaret } \\
\text { etmektedir. }\end{array}$ \\
\hline
\end{tabular}

Filmin son sahnesi olan resim 25'de iki insanın nasıl birlikte olup tekliğe ulaştığ1 görünür. Ayrıca kadın ve erkekten oluşan bu tek olma durumu gerçeklikte bir hiç olarak algılanmaktadır. Tartıda iki insanın ağırlı̆̆ının olmaması bu yokluğu simgeler. Sun-hwa'nın daha önceki sahnelerden birinde tartıyı bozması, bu hiçliği istediğini gösterir.

\section{Sonuç}

Güney Kore sinemasının önemli yönetmenlerinden biri olan Kim Ki-duk, filmlerinde genellikle şiddet ve cinsellik temalarını kullanır. Bu temaların kullanımı yönetmenin toplumsal işleyişe bir tepkisidir. Kim Ki-duk, bir röportajda, çocukluğunda ve askerde şiddet gördüğünü açıklar. Freudyan psikanaliz yaklaşımı çerçevesinde ele alınırsa, yönetmenin bastırılan şiddet olgusunu bilinçaltından filmlerine yönelttiği sonucuna varılabilir. Film içerisinde de özellikle erkek egemen temsillerde şiddet önemli bir tanımlayıcı unsur olarak sunulur. Şiddetin karșısına ise suskunluk yerleștirilerek filmin iki zıt yapı ile karakterlerin ilişkilendirilmesi sağlanır. Filmdeki sessizlik, özellikle önce ana karakter olan Tae-suk ve sonrasında ise Sun-hwa'nın üzerinden verilir. Susma edimi, çoğu sahnede bir kabullenişten ziyade bir haykırıştır. Bu filmin genelinde intikam duygusu farklı bir boyutta görülür. Bu duygu genel olarak erkek karakterler üzerinden sunularak intikam, güç olgusu ile erkek temsili ile ilişkilendirilir. Film içinde golf topu, aslan heykeli gibi simgeler güç olgusunun görsel sunumudur. Kim Ki-duk film boyunca aynı intikam nesneleri kullanmıştır. Bu nesneler golf topu ve filme de adını veren golf sopasıdır. Filmin İngilizce adı olan Bin jin (3- Iron) bir golf sopasının numarasıdır Ayrıca heykeller, Kim Ki-duk'un birçok filminde yer alır. Filmin başlarında kadın heykeli, korumasızlı̆̆ kadın temsili üzerinden verirken modern binanın önünde yer alan kanatlı kadın heykeli ise özgürlüğü sunar. Bu iki kadın heykelinin farklı anlamlandırması, toplumsal bağlamda geleneksel/modern eleştirisini ortaya koyar. Ayrıca aslan heykeli güç ile ilişskilendirilerek erkek temsiline işaret etmektedir. Filmin genelinde ataerkil toplumdaki kadın/ erkek temsillerinin sürekli olarak karşılaştırıldı̆̆ı görülmektedir. Bu karşılaştırmalar bazen nesnelerle (heykel, golf topu vb.) bazen de suskunluk, öfke gibi davranışlarda yapıllır.

Filmin göstergebilimsel çözümleme ile analiz edilmesinin nedeni yönetmenin diyaloglardan ziyade göstergeler üzerinden öyküsünü sunmasıdır. Kim Ki-duk’un bu tercihinden yola çıkılarak, göstergelerin filmde diyalog ve ses unsurunun yerine geçtiği sonucuna varilabilir. Tae-suk karakterinin sessizliği toplumsal eleştiri bağlamında bir tepkidir. Filmde karakterlerin duyguların aktarımı erkek temsillerinde şiddet olgusu, kadın karakterler üzerinden ise cinsellik ile tanımlanır. Kim ki-duk, bu temsillerle kadınerkek ilişkilerine toplumsal bir eleştiri getirir. 2004 yapımı olan film, Türkiye'de 2005’te Boş Ev adıyla gösterime girmiş̧tir. Filmde, karakterlerin boş evlerde aile, aidiyet, aşk olgularını aramaları bu adın uygun olduğunu düşündürmektedir. Yönetmenin filmde zaman zaman karakterler izleyen konumuna getirilirken bazen seyirci de bu edimin bir parçası haline gelir. Burada seyircinin karakterlerle özdeşleşmesinin önüne 
geçilerek eleştirel bir bakış açısı kazanmasının amaçlandığı görülmektedir. Önce Tae-suk sonrasında ona katılan Sun-hwa sürekli olarak girdikleri evlerdeki fotoğraf ya da posterlerle fotoğraflar çekilerek kendilerini başka hayatlarla özdeşleştirirler. Aslında iki yalnız karakterler bu edimle kendilerini dışarıda yaşayan başka insanların hayatlarına adapte etmeye çalışırlar.

Filmin hikâyesinde, boş evleri tespit eden Tae-suk, o mekânlarda kendine ait bir alan gibi hareket eder. Ana karakter olan Tae-suk, film boyunca hiç konuşmaz. Filmin sonuna doğru, Tae-suk, konuşma ediminin temeli olan sesten sonra ise cismani varlığndan vazgeçip adeta bir gölge durumuna gelir. Hatta filmin sonunda gölge olarak yaşamaya başlar. Sun-hwa karakteri de onun gibi gölge olmayı seçer. Aslında burada söz konusu olan, toplumda kendilerine yer bulamayan insanların görünür olamadıkları için gölge durumuna geçmeyi tercih etmeleridir. Ana karakter olan Tae-suk'un, girdiği evler, günümüz toplumunun evrenini yansıtır. Modern, geleneksel ve tek kişilik evlerde yaşanan şiddet, cinsellik ve kadın-erkek ilişkileri fotoğraflarla verilir. Tae-suk, bu evlerin hepsinde fotoğraflara kendini dâhil ederek yalnızlı̆̆ından kurtulmaya çalışır. Bu fotoğraflara dâhil olmak ev mekânına aitlik ve beraberinde ise aileye sahip olma duyguları ile tanımlanabilir. Yalnız olmanın birlikte olmakla aynı şey olduğu üzerinde duran yönetmen, şiddeti de hayatın bir parçası olarak yansıtmaktadır. İnsanların boş bıraktıkları evlerde yalnızlığını gideren Tae-suk aşk duygusunu da bu evlerden birinde bulur Ayrıca ana karakter girip, uyuduğu evlerde bu edimlerinin kefaretini o evi temizleyerek öder. Kefaret kavramı da farklı bir bakış açısı ile sunulur.

Bin Jip (Boş Ev) filmi ile ilgili yapılan bu göstergebilimsel çözümlemede Kim Ki- duk'un simgeleri diyalog ve ses yerine kullandığ1 tespit edilmiştir. Yapılan bu çalışmada filmdeki simgelerin, güç odaklı ve erk alanı içinde tanımlandığı görülmektedir. Hikâyede güç olgusu, intikam duygusu ile ilişkilendirilmektedir. Yönetmenin boş evleri aidiyet duygusu ile sunduğu da görülmektedir. Genel olarak, bu filmde Kim Ki- duk'un duyguları diyalog ya da doğrudan anlatma yerine simgelerle sunulur

\section{Extended Abstract}

In this study, the film, originally named after Bin Jip and is called 3- Iron (Bos Ev) in Turkey, produced by Kim Ki-duk, one of the important directors in South Korea, was analyzed by semiotic analysis. Kim $\mathrm{Ki}$ - duk presents a social criticism in his films especially using the themes of violence and sexuality as well as approaching man-woman relationships from a different perspective. Kim Ki- duk highlights visuality rather than sound in his cinema. In the film called Bin Jip (3-Iron), the perspective of South Korean society, which has started to modernize but cannot completely break with tradition, regarding manwoman relationships is presented.

In this study, the film, named after Bin Jip (3-Iron) and produced by Kim Ki-duk, was analyzed by semiotic analysis. Semiotics is an analysis method that reveals meaningful structures emerging as a result of a connection between signs. Although the semiotic analysis was initially used in the analyses for literary works, it is today preferred in analyzing visual elements such as painting, photography and cinema. The contemporary representatives of the semiotics may be ranked as follows: Charles S. Peirce and Ferdinand Saussure and Roland Barthes, Levis Strauss, Umberto Eco, Algirdas Julien Greimas. While Charles Sanders Peirce considers the semiotics a science based on logic, F. Saussure uses structuralism and semiotics together in his language theory. F. Saussure intends to discuss the semiotics with culture. On the other hand, R. Barthes puts the dichotomy of denotation and connotations at the center of his theory. Roland Barthes also coined the terms of myth, metaphor, and metonymy in the semiotics method. In this analysis, an interpretation is made on the signs in the film. The reason why the semiotics analysis method was used in the study is that the director preferred symbols in his films. Avoiding metaphors in Bin Jip (3Iron) film, the director uses metaphors. Its English name 3-Iron comes from the 3 numbered golf club, the object of revenge in the movie. In the movie named after 3-Iron, the signs in the film were analyzed using the semiotic analysis method because signs were used in this film rather than dialogue and sound. The purpose of this study is to uncover the relationship among sign, signifier and signified in this film of Kim $\mathrm{Ki}$ - duk, who frequently uses symbols in his cinema. The significance of the study is that it will serve as an example for the use of the image in the semiotic analysis through Kim Ki-Duk's movie Bin Jip (3- Iron). This study is limited to Kim Ki-Duk's movie Bin Jip (3- Iron). 
25 images were selected from the Bin Jip (3- Iron) film in this study. The concepts of the sign, signifier and signified of these images and the objects and people in these images were presented in tables by associating them. These tables were placed under each image, and were interpreted by being associated in relation to the concepts of sign, signifier and signified. Some conclusions were achieved at the end of the study. In the film called Bin Jip (3-Iron), in addition to violence, sexuality, gender differences, social roles, silence is also subjected. The silence in this film refers to shouting rather than obedience especially regarding the act of silence of the main character. The sense of revenge is generally seen in a different dimension in the film. This emotion is mostly observed in male characters. Kim Ki-duk uses same revenge objects during the film. These objects are a golf ball and an iron, by which the movie is named after. The English name of the movie, Bin jin (3-Iron) is the number of a golf club.

In the film called Bin Jip (3-Iron), the signs were analyzed using the semiotic analysis method. Sound is generally independent of the act of speech in the film named after Bin Jip (3-Iron). Signs rather than dialogue and sound were used in the film. In the film, a homeless man, identifying empty houses, enters those houses and lives in those houses as his own. This man, the main character, does not speak at all throughout the movie. The man becomes a shadow by giving up first sounds and then his corporeal existence. He even starts to live as a shadow at the end of the movie. The houses to which the main character enters reflect the atmosphere of today's society. The violence, sexuality and men and women relationships in modern, traditional and one-person houses are presented by photos. The main character tries to get rid of his loneliness by including himself in the photographs in all of these houses. In this semiotic analysis made for the movie called Bin Jip (3-Iron), it has been determined that the director, using the dialogues less in this film, gives importance to visuality and therefore there are too many signs in the film. After analyzing these signs, it is seen that violence, sexuality, revenge, social roles, tradition and modernity are visually described in the film.

Keywords: Semiotics, Kim Ki-duk, Bin Jip (3-Iron)

\section{Kaynakça}

Adanır, O. (2012). Sinemada Anlam ve Anlatım. İstanbul : Say.

Akerson, F. E. (2019). Göstergebilime Giriş. İstanbul: Bilge Kültür Sanat.

Akyel, E. (2015). Film formunda tekrar Kim Ki-duk örneği. Yayınlanmamış yüksek lisans tezi, İhsan Doğramacı Bilkent Üniversitesi Ekonomi ve Sosyal Bilimler Enstitüsü Medya ve Görsel Çalışmalar Ana Bilim Dalı, Ankara.

Andrew, J. D. (2000). Sinema Kuramlar. (İ. Șener, Cev.) İstanbul: İzdüșüm Yayınları.

Bağder, D. Ö. (1999). Sinema Göstergebilimi. Dilbilim Araştrmalarn Dergisi, 142-152.

Barthes, R. (1977). Image, Music, Text. (S. Heath, Çev.) London: Fontona Press.

Barthes, R. (1993). Göstergebilimsel Serïven. (M. Rifat, \& S. Rifat, Çev.) İstanbul: Yapı Kredi Yayınları.

Büker, S. (2010). Sinemada Anlam Yaratma. İstanbul: Hayalbaz Kitap.

Çağlar, B. (2012, Aralık). Bir İletişim Biçimi Olarak Göstergebilim. LAÜ Sosyal Bilimler Dergisi, 22-34.

Fiske, J. (2014). İletişim Çalısmalarna Giriş. (S. İrvan, Çev.) İstanbul: Pharmakon Yayıncilık.

Güçhan, G. (1992). Toplumsal değģsme ve Türk Sinemasi. Ankara: İmge kitabeci.

Karakış, E. (2018). Yeni Güney Kore sinemasinda psikanaližm: Kım Kl-Duk, Lee Chang-Dong ve Park Chanwook filmlerinin rubbilimsel çözümlemesi, Kocaeli Üniversitesi Sosyal Bilimler Enstitüsü Radyo Televizyon ve SinemaAna Bilim Dalı, Kocaeli.

Kaya, G. Ş. (2011, 05). Kim Ki-duk: Kim Ki-duk'un Göstergeler Döngüsü. 06 13, 2021 tarihinde http://gizemsimsekkaya.com/wp-content/uploads/2011/05/Godfather-Sayi-6-51-58.pd adresinden alınd1

Keskin, S. (2018). Sinemada göstergebilim çalssmasina uygulamal bir örnek: Kim ki Duk'un bin j̈p filminin incelenmesi. Yayınlanmamış yüksek lisans tezi, Selçuk Üniversitesi Sosyal Bilimler Enstitüsü Radyo Televizyon Ana Bilim Dal, Konya.

Monaco, J. (2000). Bir Film Nasil Okunur? (E. Yılmaz, Çev.) İstanbul: Oğlak Yayıncilık.

Moran, B. (2002). Edebiyat Kuramlar ve Eleştiri. İstanbul: İletişim Yayınları.

Rifat, M. (2009). Göstergebilimin ABC'si. İstanbul: Say Yayınları.

Saussure, F. d. (1985). Genel Dilbilim Dersleri. (B. Vardar, Çev.) Ankara: Birey ve Toplum Yayınları. 
Sayıc1, F. (2021). Kim Ki-duk'un "Acı" filminin Göstergebilimsel Çözümlemesi. İletişim Kuram ve Arastirma Dergisi, 77-92.

Sivas, A. (2012). Göstergebilim ve Sinema Üzerine Bir Deneme. İstanbul Üniversitesi Sosyal Bilimler Dergisi(11), 527-538.

Wollen, P. (2008). Sinemada Göstergeler ve Anlam. (Z. Aracagök, \& B. Doğan, Çev.) İstanbul: Metis Yayinlar1.

Zengin, M. O. (2011). Uzakdoğu Felsefesi Işığında Yay Filminin Göstergebilimsel Çözümlemesi. İstanbul Üniversitesi İletișim Fakültesi Dergisi, 67-86. 